\title{
Legislations and Medical Practice
}

"Medicine is a sacred Calling... its desecration amounts to blasphemy".

Descartes

In 1986 the Consumer protection act was promulgated in India. Probably, nor purported for Medical profession yet, the Court settled the consumer's jurisdiction which included Medical profession. Other Countries soon adopted the Act. Thereafter, the Patients became consumers and doctors, the service provider (a dignified name for a Trader). The profession already fettered with a number of legal chains got another noose. Undeniably, this gave patient a sharp tooth against health service providers but its abuse was soon apparent, and the spurt in the Consumerism soon was rewarded by a prohibitory rising cost of the medical treatment, the legal and insurance expenses were ultimately passed on to the patient. Among recent year, as a populist measure there has been a tendency to add some more stringent criminal laws against medical practice. Though some such laws already exist.

It should be clearly understood that the Acts alone cannot contain "Actus Reus". Too many laws against medical profession will harass and exploit the medical community in unfair hands. This will lead to a non-optimal performance by the demoralized profession. Further, the medical ethics is based on the Concept of total Beneficence to patients and absence of malfeasance. This concept is a practical absurdity. The treatment, investigations and operations are done for the benefit of the patients (Beneficence) but none of them is without complications and risk ( $A$ lack of Malfeasance) and sometimes the result of operation and treatment is less than expected. The unexpected death during the treatment or operation is possible. The problem begins here, the patient party feels that there has been an act of Ommission or Commission on the part of the doctors. They vandalize the hospital, beat or even have killed the doctors and then file a case to the police. The usual repercussion is a strike by the profession leading to the death of many innocent patients who had no part in the sordid drama. Will new laws eliminate this? The answer is a humble "No".

The aphorisin is clear. The doctors will have to learn the art of good medical- practice and the patient party should clearly understand that doctors are not God. Moreover, there is Court to go for the redressal of the grievances rather than criminally assaulting the Service Providers.

The Hospital do need effective laws to prevent such happenings.

\author{
Prof. S. M. Mishra \\ MS(Surgery), MS(Ortho), FRCS \\ Editor In Chief
}

